\title{
Is there an effect of storage depth on the persistence of silver birch (Betula pendula Roth) and rowan (Sorbus aucuparia L.) seeds? A seed burial experiment
}

\author{
Katharina Tiebel, \\ Franka Huth, \\ Sven Wagner
}

\begin{abstract}
Sorbus aucuparia L. (rowan) and Betula spp. (birch) are the most common of the early successional pioneer tree species in central Europe with the ability to form a soil seed bank. Little is known about the reasons for the high variations observed in the persistence in the soil of rowan and birch seeds. The objective of this study was to assess the ability of buried birch and rowan seeds to form short-term persistent soil seed banks and to analyse the influence of burial depth on seed persistence. An artificial seed burial experiment was initiated to study the persistence of birch seeds and rowan seeds, with and without pulp, stored at depths of 2,5 and $10 \mathrm{~cm}$ in mineral soil over 2.5 years. The predicted maximum storability periods for buried birch seeds was 13 years, compared to 4.5 years for rowan seeds with pulp and 3.5 years without pulp. The lower storage capacity of rowan seeds was demonstrated by germinations in the darkness within soil of $3-22 \%$ of seeds without pulp and $4-48 \%$ of seeds with pulp. Germination percentages of birch and rowan with and without pulp did not differ between depths. Only burial duration had an effect for either tree species. Birch and rowan seeds are able to form short-term persistent soil seed banks. Birch accumulates a seed reserve in the soil over time, until a change in conditions conducive to germination occurs, while rowan seeds germinate promptly after overcoming seed dormancy. The pulp provides no benefits in relation to the persistence of rowan seeds; rather, it appears to act as a physical inhibitor of germination. Therefore, annual input of fresh seeds is required for the success of rowan. Seed input every few years seems sufficient to guarantee a minimum number of viable birch seeds.
\end{abstract}

Keywords: Soil, Propagule Bank, Seed Longevity, Germination Within Soil, Pioneer Trees, Dormancy

\section{Introduction}

Soil seed banks are reservoirs of viable seeds stored in the soil (Bossuyt \& Honnay 2008). The adaptive value of a soil seed bank is to prevent germination under unfavourable site conditions (Bradbeer 1988, Saatkamp et al. 2014) and thus enable a seed crop to germinate over an extended period of time, i.e., "dispersal in time" (Falahati-Anbaran et al. 2014). Once optimal site conditions arise, for example, following a storm, the buried seed reserves make feasible a fast colonisation of the disturbed site. Soil seed banks are an impor- tant component of the regeneration of disturbed areas, but in general they also are an important driver of succession dynamics in ecosystems (Hille Ris Lambers et al. 2005, Bossuyt \& Honnay 2008).

Soil seed banks mainly contain light-demanding species and disturbance-adapted species of early or middle successional stages with small and compact seeds (Schwienbacher et al. 2010, Gomes et al. 2019). The largest group of light-demanding species in forest soils is herbaceous plants (Jankowska-Blaszczuk 1998, Zobel et al. 2007), but there are also light-de-

TU Dresden, Institute of Silviculture and Forest Protection, Chair of Silviculture, Pienner Str. 8, 01737 Tharandt (Germany)

@ Katharina Tiebel (katharina.tiebel@forst.tu-dresden.de)

Received: Oct 28, 2020 - Accepted: Mar 21, 2021

Citation: Tiebel K, Huth F, Wagner S (2021). Is there an effect of storage depth on the persistence of silver birch (Betula pendula Roth) and rowan (Sorbus aucuparia L.) seeds? A seed burial experiment. iForest 14: 224-230. - doi: 10.3832/ifor3685-014 [online 2021-05-06]

Communicated by: Emilia Allevato manding, early successional pioneer tree species (Dalling et al. 1997, Hille Ris Lambers et al. 2005). Some tropical pioneer tree species are known for the long-term persistence of seeds in soil (Dalling et al. 1997) and also some early successional pioneer species in temperate woodlands of America, for example, Prunus pensylvanica (up to 30 years) and Robinia pseudoacacia (from just a few years to 40 years - Toole $\&$ Brown 1946, Anderson 2004, Hille Ris Lambers et al. 2005, Masaka et al. 2010). In the temperate forests of Europe, the most common woody colonisers of disturbed sites are the pioneer species Betula spp., Salix spp., Populus spp. and Sorbus aucuparia $\mathrm{L}$. These species have received little consideration in earlier soil seed bank studies. Rowan (Sorbus aucuparia) and birch (Betula spp.) were chosen for this study because these are the most common pioneer tree species in central Europe with the ability to form a soil seed bank (Tiebel et al. 2018). Hill (1979) and Erlbeck (1998) espoused the opinion that rowan seeds remain viable in the soil for up to five years due to embryo and seed coat dormancy (Raspé et al. 2000). However, Tiebel et al. (2018) rarely found rowan seeds in soil 
seed banks in forests and assumed that the persistence of rowan seeds in the soil might be less than one year (Dölle \& Schmidt 2009). The assumptions about the duration of birch seed storage in the soil vary from less than one year to more than 13 years (Skoglund \& Verwijst 1989, Buckley et al. 1997). The high degree of variation of rowan and birch seed persistence begs the question whether contrasting soil moisture or burial depth may lead to these differences. It is well known that in moist soil and flooded areas the seeds of dry-habitat species lose their viability more rapidly due to pathogen attack and predation in wet than in dry soil (Skoglund \& Verwijst 1989, Bekker et al. 1998, Hille Ris Lambers et al. 2005, Van et al. 2005). Generally, little is known about the storability of buried tree seeds in the soil as a function of mineral soil depth (Toole \& Brown 1946, Van et al. 2005). Zhang et al. (2019) and Mennan (2003) observed for some weed species a trend of reducing seed viability loss with increasing soil depth. This evidence is lacking for tree species of temperate woodlands, thus it deserves specific investigations. In the case of rowan another question arises: does the pulp have an influence on seed longevity in soil by triggering fruit-induced secondary dormancy (Devillez 1979, cited in Raspé et al. 2000, Bewley 1997)? Granström (1987) observed rowan seed germination within soil before excavation of the buried seeds.

To answer these questions, we performed an artificial seed burial experiment aimed to study whether birch and rowan establish a short-term persistent soil seed bank. The effect on seed viability of different storage depths within the mineral soil was also assessed for birch seeds and rowan seeds with and without pulp. The following hypotheses were formulated at the outset of the study: (1) birch seeds remain viable in the soil longer than rowan seeds with and without pulp, because rowan seeds will germinate within the soil during the storage period; (2) the pulp surrounding rowan seeds offers benefits in terms of seed longevity in the soil, because the pulp prevents early germination of seeds within soil; (3) rowan and birch seed germination percentages shows no differences between deep and shallow soil.

Tab. 1 - Overview of birch and rowan seed collection.

\begin{tabular}{|c|c|c|c|c|c|}
\hline Species & $\begin{array}{l}\text { Date of } \\
\text { collection }\end{array}$ & Landscape & $\begin{array}{l}\text { Approximate } \\
\text { location }\end{array}$ & $\begin{array}{l}\text { Seed } \\
\text { trees }\end{array}$ & $\begin{array}{l}\text { Inflorescences } \\
\text { per tree }\end{array}$ \\
\hline \multirow{3}{*}{$\begin{array}{c}\text { Betula } \\
\text { pendula }\end{array}$} & 02.09 .2015 & Göttingen - road site & $51^{\circ} 33^{\prime} \mathrm{N}-09^{\circ} 56^{\prime} \mathrm{E}$ & 3 & 10 \\
\hline & 07.09 .2015 & Thuringian forest & $50^{\circ} 40^{\prime} \mathrm{N}-10^{\circ} 45^{\prime} \mathrm{E}$ & 3 & 10 \\
\hline & 10.09 .2015 & Tharandter forest & $50^{\circ} 57^{\prime} \mathrm{N}-13^{\circ} 30^{\prime} \mathrm{E}$ & 3 & 10 \\
\hline \multirow{3}{*}{$\begin{array}{c}\text { Sorbus } \\
\text { aucuparia }\end{array}$} & 03.09 .2015 & Göttingen - road site & $51^{\circ} 33^{\prime} \mathrm{N}-09^{\circ} 56^{\prime} \mathrm{E}$ & 3 & 10 \\
\hline & 12.09 .2015 & Thuringian forest & $50^{\circ} 40^{\prime} \mathrm{N}-10^{\circ} 45^{\prime} \mathrm{E}$ & 3 & 10 \\
\hline & 10.09 .2015 & Tharandter forest & $50^{\circ} 57^{\prime} \mathrm{N}-13^{\circ} 30^{\prime} \mathrm{E}$ & 3 & 10 \\
\hline
\end{tabular}

seeds can germinate even at temperatures as low as $2^{\circ} \mathrm{C}$ (Barclay \& Crawford 1984) to $5{ }^{\circ} \mathrm{C}$ (Grime et al. 1981). Germination can also occur in light as well as in darkness and at soil pH < 7.0 (Devillez 1979, cited in Raspé et al. 2000). which produces small and light wind-dispersed seeds with wings (Perala \& Alm 1990). The seeds are $1.5-2.0 \mathrm{~mm}$ in size (Brouwer \& Stählin 1975), weigh 0.12-0.25 mg (Atkinson 1992) and are mainly dispersed from June to November (Perala \& Alm 1990) over mean distances of 40-400 m (Huth 2009, Tiebel et al. 2020). Birch seed trees usually have a mast year every 23 years, at which time seed viability is increased (Sarvas 1948). The light-demanding seeds commonly germinate in spring, as snow is melting and the temperature increasing. Birch seeds exhibit no dormancy but the germination percentage benefits from moist pre-chilling of seeds. More favourable germination conditions are temperatures between $20-30{ }^{\circ} \mathrm{C}$ and a long-day photoperiod (Perala \& Alm 1990, Atkinson 1992, Midmore et al. 2015). Birches are tolerant to different soil conditions, therefore, the seeds can germinate and establish on sites with soil pH between 3.5 and 7.8 (Atkinson 1992). Litter and soil cover hinder the germination of birch seeds (Perala \& Alm 1990, Atkinson 1992).

Rowan (Sorbus aucuparia L.) is also a pioneer tree species. It is shade-tolerant when young and becomes increasingly light-demanding with age (Prien 1964). Rowan trees produce red fruits with small seeds (1.2-4.0 mm in size - Brouwer \& Stählin 1975), whose masses range between 1.15$4.14 \mathrm{mg}$ (Raspé et al. 2000). Mast years occur every 2-5 years (Satake et al. 2004). The fruits ripen from August to October and are endozoochorously dispersed by small mammals and birds (Raspé et al. 2000). Birds, the main vectors of long distance seed dispersal, mostly defecate rowan seeds at distances of 40-100 $\mathrm{m}$ from the seed tree (Stiebel 2003, Zywiec et al. 2013). Embryo and seed coat dormancy are well documented for rowan. When the fruits are not eaten by animals, dormancy must be broken under natural conditions (Raspé et al. 2000). A second period of dormancy can be caused by the temperature rising above $10{ }^{\circ} \mathrm{C}$ within a short period of time after the winter (Spethmann 2000). Rowan

\section{Study area}

The burial experiment was located at the colline and submontane belts of the Tharandter Forest $\left(50^{\circ} 57^{\prime} \mathrm{N}, 13^{\circ} 30^{\prime} \mathrm{E}\right)$ in the German Federal State Saxony (Fiedler \& Hofmann 1978). The study area is situated between $200-460 \mathrm{~m}$ a.s.l., on the northern edge of the eastern Ore Mountains (Erzgebirge), at the transition from hill country to low mountain range (Fiedler \& Hofmann 1978 , Nebe 1982). The annual average temperature in the region varies between 7.3 and $7.7{ }^{\circ} \mathrm{C}$ and the mean annual precipitation ranges from 819 to $850 \mathrm{~mm}$ (Goldberg et al. 2002). The area is moderately subcontinental (Nebe 1982). The geology of the region has given rise to medium to deep brown soils that predominate on the forest sites, as well as dry sands and podzols with low nutrient contents and silty brown earths (Nebe 1982, Schwanecke \& Kopp 1996). For the seed burial experiment, an old, pure coniferous forest in the Tharandter Forest with a closed canopy and no ground vegetation (only litter) was chosen. These coniferous forests are particularly exposed to storms and soil seed banks are important for natural regeneration. The soil type of the forest stand is pseudogleybrown earth, whose $\mathrm{pH}$ value generally varies between 3.5 and 5.5.

\section{Experimental design and data collection}

Birch (Betula pendula) seeds and rowan (Sorbus aucuparia) fruits were collected from mature seed trees on 2-12 September 2015, a few days before they were buried in the soil. At each of the three sampling locations in Germany (Tab. 1), 10 inflorescences each were harvested from three birch and three rowan seed trees. As the seeds and fruits were mixed, the seeds could not later be traced back to individual trees or locations.

A total of 400 fresh birch and rowan seeds were used to test the initial germination capacity, according to the methods of the International Seed Testing Association (ISTA 2012). Four germination samples (4 replicate with 100 seeds) were prepared by placing birch seeds in germinators on moist filter paper. The germinators were placed in a climatic chamber for 21 days under constant conditions $\left(25^{\circ} \mathrm{C}, 80 \%\right.$ humidity, $16 \mathrm{~h}$ light and $8 \mathrm{~h}$ dark) and checked weekly. The rowan seeds were cold-wet stratified for 4 months at $5{ }^{\circ} \mathrm{C}$ in trays with moist sand and darkness before starting the germination test. After stratification the four trays (4 replicate with 100 seeds) were placed in the cold greenhouse for 28 days, where daily temperatures varied between $10-15{ }^{\circ} \mathrm{C}$. The germination process was checked weekly. 
On 25 September 2015, the birch and rowan seeds and fruits were inserted separately into $10 \times 20 \mathrm{~cm}$ net bags filled with soil and sewn up (hereinafter referred to as seed sets). The bags had a mesh size of 1.5 $\times 1.5 \mathrm{~mm}$. After six to twelve months the seams of the bags had opened and access to the seeds for mesofauna was no longer impeded. While removing rowan seeds from the pulp for the purposes of the experiment, it was possible to determine an average seed number per fruit and calculate the number of fruits required to give 50 seeds per bag. Each bag contained either 50 birch seeds, 50 rowan seeds or 18 rowan fruits (approx. 50 rowan seeds). On 25 October 2015, in total 90 bags were buried in mineral soil at depths of $2 \mathrm{~cm}, 5$ $\mathrm{cm}$ and $10 \mathrm{~cm}$ at two separate plots in the same coniferous stand ( $8 \mathrm{~m}$ apart) to spread the risk of damage to the seeds or plots by mice or wild boars. After burial of the bags, the humus and litter layer were carefully restored to their prior state.

At intervals of six months between April 2016 and April 2018, seed sets (one bag per seed set, layer and plot) were removed from the soil to collect 100 seeds from each seed set and layer to test the viability of the stored seeds by germination tests. The "seedling emergence method" was used for both species (Falinska 1999), but it was adapted to the particular germination ecology of each species. The seeds in the bags with soil were filled separately into trays after each excavation. The trays with the birch seed sets were always placed in a climate chamber at a constant $25{ }^{\circ} \mathrm{C}, 80 \%$ relative humidity and $16 \mathrm{~h}$ lighting per day for three months to assess germination percentage. The trays with the rowan seed and rowan fruit sets were always placed in a greenhouse under varying temperatures, relative humidity and day-night light regime for one year. The mean day-night temperature ranged from -5 to $26^{\circ} \mathrm{C}$ in win- ter and from 9 to $34^{\circ} \mathrm{C}$ in summer, and the mean day-night humidity varied between $34 \%$ and $99 \%$ in winter and $51 \%$ and $100 \%$ in summer. The soil of all samples was kept continuously moist through regular watering in climate chamber and greenhouse. The frequency of watering depended on temperature, air humidity and sunlight in the greenhouse. In the first month, every week the number of successfully germinated seeds was recorded. Thereafter, germination was checked every 14 days.

\section{Statistical analysis}

The recorded germination percentages were not corrected for previous germination percentages and seed mortality or time intervals to represent the observed germination loss over the storage time of seeds in soil.

The aim of the study was to assess the effect of storage time and burial depth on the quantity of germinated seeds after excavation. Due to the nested experimental design a mixed modelling approach was used. The response variable (germination percentage) was not normally distributed, thus we used generalized linear mixed models (GLMM). The nested random effects in the model was the plot number and net bag number. The net bags were included as a random effect because each of the 50 seeds in a net bag were considered as one germination observation in the data frame. We tested separately for each tree species seed set whether the number of germinated seeds within a seed set depends on the fixed effects: storage time (continuous variable) and depth in the soil (3-level categorical variable). The interaction between the fixed effects was also tested. The "glmmADMB" package version 0.8.3.3 was applied to model the GLMM in $R$ software version 3.3.2 ( $R$ Core Team 2014). The package "glmmADMB" used the automatic differentiation model builder
$(A D M B)$ to fit the parameters (Bolker et al. 2012). The advantages of ADMB are: (i) the range of distribution families; (ii) the range of link functions; and (iii) the use of the MCMC method (Markov chain Monte Carlo) to summarise uncertainties (Zuur et al. 2009, Bolker et al. 2012). As seed germination is an absence-presence event, that is, the data distribution is binomial, the model link function was set to logit (Zuur et al. 2009). Significant differences in all models were accepted at $p<0.05$. The necessary homoscedasticity of variance and normality were checked and confirmed with plots of residuals and quantiles from fitted GLMM. Overdispersion has no relevance in a binomial model with binary data. The terms "initial germination capacity (\%)" and "percentage of germination (\%)" were used to delimit the initial germination percentage of the collected fresh birch and rowan seeds and the regularly recorded remaining viability percentage of buried seeds.

\section{Results}

\section{Birch seed}

The initial germination capacity of freshly harvested birch seeds before burial was $32 \%$ (Fig. 1a). Over the period of storage in the soil, the percentage of germination varied between 0-37\% without a detectable effect of storage depth (Fig. 1a, Tab. 2). The quantity of germinated seeds was always higher in spring (19-37\%) than in autumn (0$31 \%$ ). In April 2018, after 2.5 years in the soil, the percentage of germination was as high as at the beginning of the experiment. The GLMM results reveal a weak significant influence of storage time ( $p$-value $=0.074$ ), but there was no influence of burial depth or interaction between these two effects on seed germination (Tab. 2, Fig. 2). The model predicts that the birch seeds would have lost all viability after 13 years. No ger-
Fig. 1 - (a) Percentage of germination (\%) of birch seeds (top), rowan seeds (middle) and rowan fruits (bottom) stored in mineral soil at depths of 2, 5 and $10 \mathrm{~cm}$ in a coniferous forest. (b) Early seed germination within soil (\%) relative to the total seeds buried in mineral soil at depths of 2, 5 and 10 $\mathrm{cm}$ for birch seeds (top), rowan seeds (middle) and rowan fruits (bottom) before excavation of the seed sets. The percentage of germination and the early seed germination within the soil were checked at intervals of 6 months from April 2016 to April 2018.

Mature seeds and fleshy fruits were buried in October 2015 after the initial germination capacity (\%) had been tested according to ISTA (2012). Note the different scales on the $y$-axes.
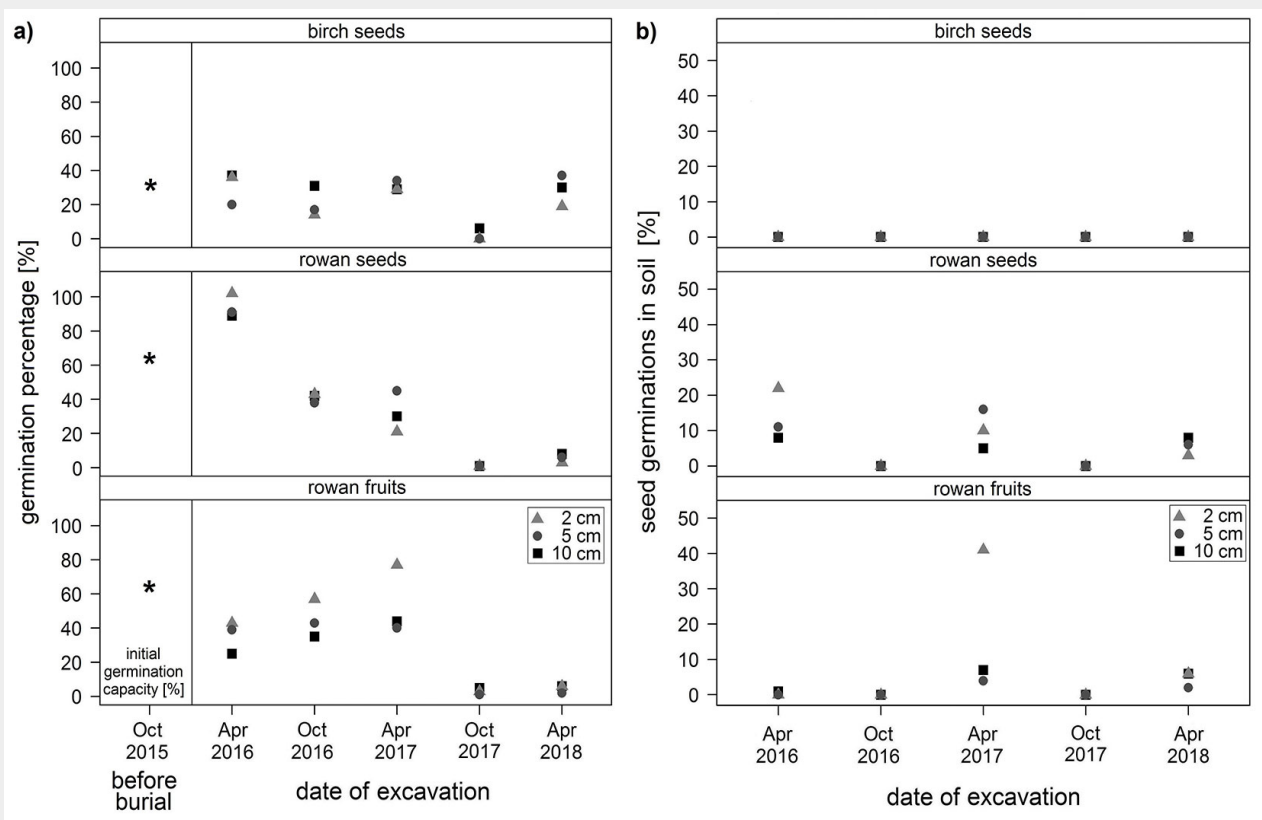
Tab. 2 - GLMM results for the percentage of germination of the buried seed sets, stored over 2.5 years in mineral soil at depths of 2, 5 and $10 \mathrm{~cm}$ in two study plots in a coniferous forest. (f): fixed effects; ( $\mathrm{r}$ ): random effects; (ns): not significant; (SD): standard deviation; (plot): plot number; (net bag): number of the net bag for each plot and storage depth. The reference (intercept) is the seed set buried at depths of $2 \mathrm{~cm}$ in the mineral soil.

\begin{tabular}{|c|c|c|c|c|c|c|c|}
\hline $\begin{array}{c}\text { Seed } \\
\text { sets }\end{array}$ & Effects & Estimate & Std. error & z-value & $p$-value & Variance & SD \\
\hline \multirow{6}{*}{ 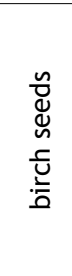 } & f intercept & -0.917 & 0.401 & -2.29 & 0.022 * & - & - \\
\hline & f storage time & -0.213 & 0.119 & -1.79 & 0.074 & - & - \\
\hline & f storage depth $5 \mathrm{~cm}$ & 0.036 & 0.258 & 0.14 & $0.888^{\text {ns }}$ & - & - \\
\hline & $\mathrm{f}$ storage depth $10 \mathrm{~cm}$ & 0.161 & 0.257 & 0.63 & $0.530^{\mathrm{ns}}$ & - & - \\
\hline & r plot & - & - & - & - & 0.000 & 0.003 \\
\hline & r net bag & - & - & - & - & 0.935 & 0.967 \\
\hline \multirow{6}{*}{ 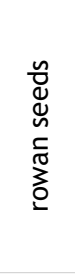 } & f intercept & 2.698 & 0.530 & 5.09 & $<0.001^{* * *}$ & - & - \\
\hline & f storage time & -1.331 & 0.166 & -8.03 & $<0.001 * * *$ & - & - \\
\hline & f storage depth $5 \mathrm{~cm}$ & 0.012 & 0.269 & 0.04 & $0.960^{\mathrm{ns}}$ & - & - \\
\hline & f storage depth $10 \mathrm{~cm}$ & 0.003 & 0.269 & 0.01 & $0.990^{\mathrm{ns}}$ & - & - \\
\hline & r plot & - & - & - & - & 0.000 & 0.006 \\
\hline & r net bag & - & - & - & - & 1.620 & 1.273 \\
\hline \multirow{6}{*}{ 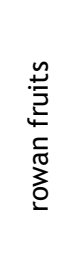 } & f intercept & 1.089 & 0.501 & 2.17 & 0.030 * & - & - \\
\hline & f storage time & -0.843 & 0.160 & -5.27 & $<0.001^{* * *}$ & - & - \\
\hline & f storage depth $5 \mathrm{~cm}$ & -0.173 & 0.269 & -0.64 & $0.520^{\mathrm{ns}}$ & - & - \\
\hline & $\mathrm{f}$ storage depth $10 \mathrm{~cm}$ & -0.152 & 0.268 & -0.57 & $0.570^{\text {ns }}$ & - & - \\
\hline & r plot & - & - & - & - & 0.000 & 0.005 \\
\hline & $r$ net bag & - & - & - & - & 1.546 & 1.244 \\
\hline
\end{tabular}

mination in soil was observed for birch (Fig. 1b).

\section{Rowan seed}

The initial germination capacity of freshly harvested rowan fruits was $64 \%$. After the first winter period in soil, the percentage of germination of buried rowan seeds reached $89-99 \%$, which clearly exceeded the initial germination capacity and was not observed in any other seed sets over the whole observation period (Fig. 1a). From April 2016 to April 2018, the number of germinated rowan seeds decreased significantly with increasing storage time (3$8 \%$, which was confirmed by the model results (Tab. 2, Fig. 2). The predicted maximum storability period was 3.5 years. The model revealed no significant influence of storage depth and interaction between fixed effects.
Seeds germinated within the soil were observed during the excavation. The highest germination within the soil occurred in the first spring after burial and were exhibited by the seeds buried at $2 \mathrm{~cm}$ (22\% - Fig. 1b). After 2.5 years of storage the germination at $2 \mathrm{~cm}$ decreased to $3 \%$. At $10 \mathrm{~cm}$ soil depth the number of seeds germinated within the soil remained similar over time. The model results showed that overall there was no effect of storage time, storage depth, or any effect of their interaction, on seed germination within the soil (result not shown).

\section{Rowan fruits}

Rowan seeds with pulp exhibited an initial germination capacity of $64 \%$ in October 2015. After the first winter period, only 25 $43 \%$ of the buried seeds with pulp germinated (Fig. 1a). The germination subse- quently increased in all soil layers until April 2017 (40-77\%) before most seeds in pulp lost viability after two years of storage in the soil (1-6\%). The negative influence of storage time is also shown by the model results (Tab. 2, Fig. 2), which predict a complete loss of seed viability after 4.5 years in soil. The germination percentage at $2 \mathrm{~cm}$ soil depth was always higher than in the deeper soil layers, but the model results confirmed no significant differences in germination numbers on the basis of storage depth. No interactions between the fixed effects were detected.

The presence of germinated seeds in the soil was also observed for the rowan seeds with pulp prior to the excavation of the net bags. The first time this observation was made in the second spring after burial, when the germination within the soil reached $4-48 \%$. The highest germination
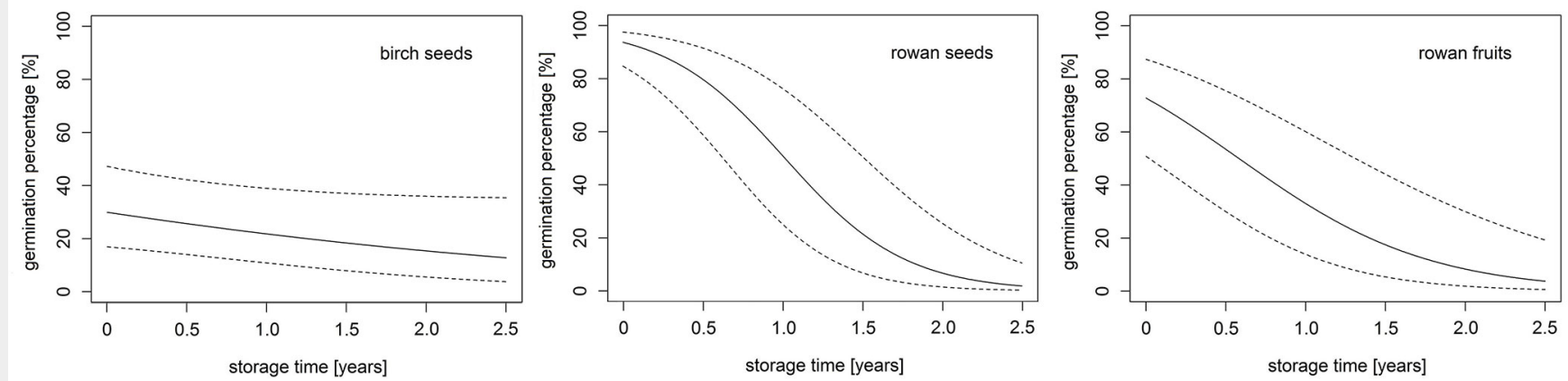

Fig. 2 - GLMM predictions of germination percentage (\%) for birch seeds (left), rowan seeds (center) and rowan fruits (right) in soil over the 2.5-year study period. 
percentages within soil always occurred at $2 \mathrm{~cm}$ soil depth, after the pulp had begun to decompose (Fig. 1b). Rowan fruits buried at depths of $5 \mathrm{~cm}$ and $10 \mathrm{~cm}$ exhibited no morphological changes after the first winter, whereas at $2 \mathrm{~cm}$ the pulp was soft and had started decomposing. By the autumn 2016, no fruits were detected at 2 $\mathrm{cm}$ while in the deeper layer the pericarps were still hard and intact. In the second autumn (2017), no fruits were found in any layer. The model results revealed no significant influence of fixed effects on germination within soil.

\section{Discussion}

\section{Seed persistence in soil}

The results revealed a markedly longer duration of seed storability in soil for smaller birch seeds than for larger rowan seeds, either with or without pulp, which confirmed our first hypothesis. It is a well-established hypothesis that seed longevity is strongly correlated to seed size, mass and shape (Bakker et al. 1996a, 1996b, Plue et al. 2010). Smaller, spherical seeds with a hard seed coat tend to have longer seed longevity than large, elongated and flattened seeds (Bakker et al. 1996b, Schwienbacher et al. 2010). Bakker et al. (1996b) mentioned that small and low-mass seeds may better penetrate into deeper soil layers.

The model finding a birch seed persistence of 13 years in soil showed a clear trend of birch seed longevity in the soil. But the own data corresponded not to the longevity determined by Skoglund \& Verwijst (1989), who derived a theoretical seed half-life of 13 years for B. pubescens seeds. A buried seed experiment by Granström (1987) revealed viability of at least five years for $B$. pendula and B. pubescens seeds. Bakker et al. (1996a) categorised birch as having a short-term to long-term persistent soil seed bank (seeds are viable $>1-5$ years in soil - Thompson et al. 1997). No germination of birch seeds within the soil was observed in our study. The absence of seed germination within the soil ensures the accumulation of birch seeds in the soil as a seed reserve. We conclude that birch belongs to at least the shortterm persistent type and that a replenishment of the soil seed bank with fresh seeds is required every few years.

Most of the buried rowan seed sets in our study, with and without pulp, exhibited very low percentage of germination (3-13\%) after two years and produced a predicted maximum seed persistence of 3.5-4.5 years. Similar forecasts about rowan seed longevity were made by Hill (1979) and Erlbeck (1998). Granström (1987) found 60\% of rowan seeds to be viable after three years, but only one seed germinated after five years. The declining viability in Granström's study largely reflected our findings. Therefore, the classification of rowan as transient (viable $<1$ year) by Grime et al.
1988 (cited in Raspé et al. 2000) and Dölle \& Schmidt (2009) appears incorrect and suggests rowan seeds should be re-classified as short-term persistent, although the seeds are more short-lived than birch seeds.

The hard-coated seeds of rowan are smaller and lighter than the long-term persistent Robinia pseudoacacia seeds (Hille Ris Lambers et al. 2005), which have a mean seed length of $4.9 \mathrm{~mm}$ and a mean seed mass of $18.7 \mathrm{mg}$ (Cierjacks et al. 2013). Therefore, rowan seeds may more readily drift into the soil than Robinia pseudoacacia seeds and would also have to form a longterm soil seed bank, according to Bakker et al. (1996a, 1996b) and Plue et al. (2010).

The low storability of rowan seeds in the artificial burial experiment can be explained by early seed germination within the soil before excavation of the seed bags. Schafer \& Chilcote (1967) and Bradbeer (1988) described the phenomenon of early seed germination within soil in other species, indicating that it is not specific to rowan.

We observed early germination within the soil of rowan seeds without pulp in each spring, and germination of the rowan seeds with pulp only after the second and third winter, in accordance with Granström (1987). Under natural stratification conditions (varying moisture and temperature conditions), the dormancy of rowan seeds without pulp will be broken after 24-28 weeks (Barclay \& Crawford 1984, Afroze \& Reilly 2015), which corresponded to our findings. To overcome dormancy, rowan seeds in fruits required longer periods of cold treatment because the pericarp must first decompose before the fruit-induced dormancy could be broken (Devillez 1979, cited in Raspé et al. 2000, Barclay \& Crawford 1984, Bewley 1997). After breaking dormancy, rowan seeds usually germinate within soil even without the occurrence of a disturbance event (Granström 1987), because the seeds have the ability to germinate in darkness (Devillez 1979, cited in Raspé et al. 2000). This leads to the loss of the buried seed reserve (Schafer \& Chilcote 1967). There is no sufficient accumulation of rowan seeds in the soil to serve as a seed reserve until the prevailing environmental conditions change. Therefore, the rowan soil seed bank does not meet the definition of a classical soil seed bank as a seed reserve (Thompson et al. 1997, Bossuyt \& Honnay 2008). Unlike birch, rowan requires a constant supply of seeds to maintain a seed reserve within the soil.

\section{Influence of pulp on rowan seed persistence in soil}

The results showed that the pulp surrounding rowan seeds offers no benefits in terms of either persistence or preventing early germination in soil, refuting our second hypothesis. The model estimates about one year longer storability of rowan seed with pulp in soil, compared to rowan seed without pulp, and this is due to the need to overcome fruit-induced, embryo and seed coat dormancies (Bewley 1997, Raspé et al. 2000). Observations made during the excavations of the net bags from the soil revealed that the decomposition of the rowan pulp starts after the first winter period in the upper soil layer, where decay proceeds faster than in the deeper mineral soil layers. Granström (1987) documented the decay of rowan fruits in soil over two years, with the first germination of seeds within the soil after the second winter. This corresponded with our results.

In deeper soil layers, decomposition of the pulp was found to start later and proceed more slowly. Sometimes the exocarps were not destroyed in the lower soil layer, with the pulp having become dry and hard, and remaining wrapped around the seeds. The dry mesocarp means that there was not enough water in the deeper layer to leach away the inhibitors in the mesocarp and break dormancy. As a result, swelling and breathing of the seeds was inhibited and the seeds could not germinate. As was the case for rowan seed without pulp, seed with pulp does not store in the soil over longer periods.

\section{Influence of burial depth on seed persistence}

There is solid evidence of the importance of seed protection and seed viability provided by litter and humus cover (Toole \& Brown 1946, Van et al. 2005). Litter protects seeds against, for example, predation and drought, and prevents early germination in light-demanding seeds (Grime et al. 1981, Perala \& Alm 1990, Atkinson 1992). However, the burial depth had no influence on either seed longevity or on the quantity of germinated seeds within soil, nor was there an effect in interaction with storage time. As a consequence, we could confirm our third hypothesis.

Rowan seeds germinated in the soil regardless of depth or pulp because they do not have a light requirement for germination (Devillez 1979, cited in Raspé et al. 2000). As a consequence, no effect of soil depth was evident in the model. However, a comparison of different birch burial experiments revealed that birch seeds sown on bare ground remained viable over a period of up to three years (Miles 1974), whereas birch seeds buried under a litter layer to a depth of $10 \mathrm{~cm}$ in the mineral soil remained viable for 5 and more than 13 years, respectively (Granström 1987, Skoglund \& Verwijst 1989). The reasons underlying the lack of any effect of burial depth on birch seed longevity in our study may have been: (1) that the effect only occurs between the humus and the mineral soil layer, but not within mineral soil layers: (2) only long-term persistent species, like Potentilla norvegica L., exhibit higher seed viability in deeper soil layers (Toole \& Brown 1946). Maybe short-term persistent seeds possess the same seed longevity in deeper 
soil layers as in the upper soil layer; (3) it is also possible that the duration of the study was not long enough to detect such significant differences within the mineral soil. It was only after 10 years that Toole \& Brown (1946) observed significantly higher seed viability percentages in the deepest soil layer for the Rosaceae Potentilla norvegica.

\section{Conclusions}

The artificial seed burial experiment proved the ability of birch and rowan seeds to form a short-term persistent soil seed bank, with no influence of the storage depth in the soil. The findings of our study indicate that birch seed may in theory persist in the mineral soil for a maximum of 13 years, independent of the burial depth. Silver birch is able to build up a short-term to long-term soil seed bank until the prevailing environmental conditions change to allow for successful germination. In contrast, rowan seeds with and without pulp germinated within the soil after the breaking of dormancy, independent of the soil depth. This significantly limited the seed reserve in the soil over time. The duration of the persistence of rowan seeds in the mineral soil is a maximum of 3.5 years without pulp and 4.5 years with pulp. The pulp offers no benefits for seed persistence; rather, it would appear to act as a physiological inhibitor of germination and ultimately leads to reduced seed viability. A continuous, almost annual input of rowan seeds to the soil seed bank is necessary for successful regeneration, whereas birch seed input every few years seems sufficient.

Only the soil seed bank of birch might be exploited to make a significant contribution to the regeneration of disturbed forest sites or succession sites. Any contribution by the soil seed bank of rowan will be accidental and insufficient.

\section{Acknowledgements}

The work carried in this study was supported financially by a scholarship granted to KT by the foundation "Deutsche Bundesstiftung Umwelt" (DBU) and the "Graduiertenakademie" (GA) of the TU Dresden. We would like to thank Antje Karge, Angelika Otto and Katja Skibbe for assistance in the greenhouse and Kathrin Tiebel for sewing the seed bags. We thank David Butler Manning for proofreading the text and Jan Plue for helpful tips.

This paper is a part of the KT's dissertation (Tiebel K, 2020. The ability of pioneer tree species to mitigate the effects of site disturbance by fast and effective natural regeneration. PhD thesis, Dresden University of Technology, Germany, pp. 187), which is available at https://nbn-resolving. org/urn:nbn:de:bsz:14-qucosa2-724321.

\section{References}

Afroze F, Reilly C (2015). Effect of harvest date, drying, short-term storage and freezing after chilling on the germination of rowan seeds. Scandinavian Journal of Forest Research 31:
339-346. - doi: 10.1080/02827581.2015.1080293 Anderson MD (2004). Prunus pensylvanica. Web site. [online] URL: http://www.fs.fed.us/databa se/feis/plants/tree/prupen/all.html

Atkinson MD (1992). Betula pendula Roth (B. verrucosa Ehrh.) and B. pubescens Ehrh. Journal of Ecology 80: 837-870. - doi: 10.2307/2260870

Bakker JP, Bakker ES, Rosén E, Verwej GL, Bekker RM (1996a). Soil seed bank composition along a gradient from dry alvar grassland to Juniperus shrubland. Journal of Vegetation Science 7: 165-176. - doi: 10.2307/3236316

Bakker JP, Poschlod P, Strykstra RJ, Bekker RM, Thompson K (1996b). Seed banks and seed dispersal: important topics in restoration ecology. Acta Botanica Neerlandica 45: 461-490. - doi: 10.1111/j.1438-8677.1996.tboo806.x

Barclay AM, Crawford RMM (1984). Seedling emergence in the rowan (Sorbus aucuparia) from an altitudinal gradient. Journal of Ecology 72: 627-636. - doi: 10.2307/2260072

Bekker RM, Oomes MJM, Bakker JP (1998). The impact of groundwater level on soil seed bank survival. Seed Science Research 8: 399-404. doi: $10.1017 /$ Sog60258500004323

Bewley JD (1997). Seed germination and dormancy. The Plant Cell 9: 1055-1066. - doi: 10.1105 /tpc.9.7.1055

Bolker B, Skaug H, Magnusson A, Nielsen A (2012). Getting started with the glmmADMB package. [online] URL: http://glmmadmb.r-for ge.r-project.org/glmmADMB.pdf

Bossuyt B, Honnay O (2008). Can the seed bank be used for ecological restoration? An overview of seed bank characteristics in European communities. Journal of Vegetation Science 19: 875884. - doi: 10.3170/2008-8-18462

Bradbeer JW (1988). Seed dormancy and germination. Blackie and Son Ltd, Glasgow and London, UK, pp. 146.

Brouwer W, Stählin A (1975). Handbuch der Samenkunde für Landwirtschaft, Gartenbau und Forstwirtschaft [Seed manual of agriculture, horticulture and forestry]. DLG-VerlagsGmbH, Frankfurt am Main, Germany, pp. 655. [in German]

Buckley GP, Howell R, Anderson MA (1997). Vegetation succession following ride edge management in lowland plantations and woods. 2 . The seed bank resource. Biological Conservation 82: 305-316. - doi: 10.1016/Sooo6-3207(97) 00025-6

Cierjacks A, Kowarik I, Joshi J, Hempel S, Ristow M, Lippe Von M D, Weber E (2013). Biological flora of the British Isles: Robinia pseudoacacia. Journal of Ecology 101: 1623-1640. - doi: 10.1111/ 1365-2745.12162

Dalling JW, Swaine MD, Garwood NC (1997). Soil seed bank community dynamics in seasonally moist lowland tropical forest, Panama. Journal of Tropical Ecology 13: 659-680. - doi: 10.1017/ So266467400010853

Dölle M, Schmidt W (2009). The relationship between soil seed bank, above-ground vegetation and disturbance intensity on old-field successional permanent plots. Applied Vegetation Science 12: 415-428. - doi: 10.1111/j.1654-109X.20 09.01036.x

Erlbeck R (1998). Die Vogelbeere (Sorbus aucuparia) - ein Porträt des Baumes des Jahres 1997 [Rowan (Sorbus aucuparia) - a portrait of the tree of the year 1997]. In: "Beiträge zur Vogelbeere" (Schmidt $O$ ed). Berichte aus der Bayrischen Landesanstalt für Wald und Forstwirtschaft 17: 2-14. [in German]

Falahati-Anbaran M, Lundemo S, Stenien HK (2014). Seed dispersal in time can counteract the effect of gene flow between natural populations of Arabidopsis thaliana. New Phytologist 202: 1043-1054. - doi: 10.1111/nph.12702

Falinska K (1999). Seed bank dynamics in abandoned meadows during a 20-year period in the Bialowieza National Park. Journal of Ecology 87: 461-475. - doi: 10.1046/j.1365-2745.1999.003 64. $\mathrm{x}$

Fiedler HJ, Hofmann W (1978). Standortskundlicher Exkursionsführer "Tharandt-Grillenburger Wald" - Bodennutzung und Bodenschutz [Site-specific excursion guide "Tharandt-Grillenburger forest" - Land use and soil protection]. Technische Universität Dresden, Dresden, Germany, pp. 8o. [in German]

Goldberg V, Baums AB, Häntzschel J (2002). Klima, Boden und Landnutzung [Climate, soil and land use]. In: "Exkursions- und Praktikumsführer Tharandter Wald" (Bernhofer C, Berger FH, Goldberg V eds). Tharandter Klimaprotokolle Band 6, Dresden, Germany, pp. 15-26. [in German]

Gomes FM, Oliveira CC, Rocha Miranda R, Costa RC, Loiola MIB (2019). Relationships between soil seed bank composition and standing vegetation along chronosequences in a tropical dry forest in north-eastern Brazil. Journal of Tropical Ecology 35: 173-184. - doi: 10.1017/So2664674 19000130

Granström A (1987). Seed viability of fourteen species during five years of storage in a forest soil. Journal of Ecology 75: 321-331. - doi: 10.2307/2260421

Grime JP, Mason G, Curtis AV, Rodman J, Band SR (1981). A comparative study of germination characteristics in a local flora. Journal of Ecology 69: 1017-1059. - doi: 10.2307/2259651

Hill MO (1979). The development of a flora in even-aged plantations. In: "The Ecology of Even-Aged Forest Plantations" (Ford ED, Malcolm DC, Atterson J eds). Institute of Terrestrial Ecology, Cambridge, UK, pp. 175-192. [online] URL: http://nora.nerc.ac.uk/id/eprint/7075/1/No 07075CP.pdf

Hille Ris Lambers J, Clark JS, Lavine M (2005). Implications of seed banking for recruitment of southern Appalachian woody species. Ecology 86: 85-95. - doi: 10.1890/03-0685

Huth F (2009). Untersuchungen zur Verjüngungsökologie der Sand-Birke (Betula pendula Roth) [Study of regeneration cycle of sand birch (Betula pendula Roth)]. PhD thesis, Dresden University of Technology, Germany, pp. 383. [in German]

ISTA (2012). International rules for seed testing 2012. International Seed Testing Association ISTA, Bassersdorf, Switzerland, pp. 379.

Jankowska-Blaszczuk M (1998). Variability of the soil seed banks in the natural deciduous forest in the Bialowieza National Park. Acta Societatis Botanicorum Poloniae 67: 313-324. - doi: 10.558 6/asbp.1998.040

Masaka K, Yamada K, Koyama Y, Sato H, Kon H, Torita H (2010). Changes in size of soil seed bank in Robinia pseudoacacia L. (Leguminosae), 
an exotic tall tree species in Japan: impacts of stand growth and apicultural utilization. Forest Ecology and Management 260: 780-786. - doi: 10.1016/j.foreco.2010.05.036

Mennan $\mathrm{H}$ (2003). The effects of depth and duration of burial on seasonal germination, dormancy and viability of Galium aparine and Bifora radians seeds. Journal of Agronomy and Crop Science 189: 304-309. - doi: 10.1046/j.1439037X.2003.00048.x

Midmore EK, McCartan SA, Jinks RL, Cahalan CM (2015). Using thermal time models to predict germination of five provenances of silver birch (Betula pendula Roth) in southern England. Silva Fennica 49: 1-12. - doi: 10.14214/sf.1266

Miles J (1974). Experimental establishment of new species from seed in Callunetum in northeast Scotland. Journal of Ecology 62: 527-551. [online] URL: http://www.jstor.org/stable/2258 997

Nebe W (1982). Natürliche Grundlagen des Waldwachstums und der Waldentwicklung. Der Tharandter Wald [Natural bases of forest growth and forest development. The Tharandt Forest]. Beitrag zur Heimatgeschichte 7, Forststadt Tharandt, Tharandt, Germany, pp. 96. [in German] Perala DA, Alm AA (1990). Reproductive ecology of birch: a review. Forest Ecology and Management 32: 1-38. - doi: 10.1016/0378-1127(90)90104$\mathrm{J}$

Plue J, Verheyen K, Van Calster H, Marage D, Thompson K, Kalamees R, Jankowska-Blaszczuk M, Bossuyt B, Hermy M (2010). Seed banks of temperate deciduous forests during secondary succession. Journal of Vegetation Science 21: 965-978. - doi: 10.1111/j.1654-1103.20 10.01203.x

Prien S (1964). Untersuchungen über waldbauliche und holzkundliche Eigenschaften der Eberesche (Sorbus aucuparia L.) [Studies on silvicultural and wood science properties of the rowan (Sorbus aucuparia L.)]. PhD thesis, Dresden University of Technology, Dresden, Germany, pp. 227. [in German]

R Core Team (2014). R: a language and environment for statistical computing. R Foundation for Statistical Computing. Web site. [online] URL: http://www.r-project.org

Raspé O, Findlay C, Jacquemart A-L (2000). Sor- bus aucuparia L. Jornal of Ecology 88: 910-930. doi: 10.1046/j.1365-2745.2000.00502.x

Saatkamp A, Poschlod P, Venable DL (2014). The functional role of soil seed banks in natural communities. In: "Seeds: The Ecology of Regeneration in Plant Communities" (Gallagher RS ed). CAB International, Oxfordshire, UK, pp. 263-295. [online] URL: http://books.google. com/books?id=3Bb4AgAAQBAJ

Sarvas R (1948). A research on the regeneration of birch in south Finland. Communicationes Instituti Forestalis Fenniae 35: 82-91.

Satake A, Bjørnstad ON, Kobro S (2004). Masting and trophic cascades: interplay between rowan trees, apple fruit moth, and their parasitoid in Southern Norway. Oikos 104: 540-550. - doi: 10.1111/j.0030-1299.2004.12694.x

Schafer DE, Chilcote DO (1967). Factors influencing dormancy and persistence in buried seed of five grass species. Crop Science 10: 342-345. doi: $10.2135 /$ cropsci1970.0011183X00100004000 $7 \mathrm{x}$

Schwanecke W, Kopp D (1996). Forstliche Wuchsgebiete und Wuchsbezirke im Freistaat Sachsen [Forest growing areas and growing districts in the Free State of Saxony]. Sächsische Landesanstalt für Forsten (LAF), Graupa, Germany, pp. 191. [in German]

Schwienbacher E, Marcante S, Erschbamer B (2010). Alpine species seed longevity in the soil in relation to seed size and shape - A 5-year burial experiment in the Central Alps. Flora 205: 19-25. - doi: 10.1016/j.flora.2008.10.007

Skoglund J, Verwijst T (1989). Age structure of woody species populations in relation to seed rain, germination and establishment along the river Dalälven, Sweden. Vegetation 82: 25-34. doi: $10.1007 /$ BFo0217979

Spethmann W (2000). Generative Gehölzvermehrung [Generative propagation of woody plants]. In: “Krüssmanns Gehölzvermehrung" [Kruessmann's propagation of woody plants] (Mac Cárthaigh D, Spethmann W eds). Parey Verlag, Berlin, Germany, pp. 2-57. [in German]

Stiebel H (2003). Frugivorie bei mitteleuropäischen Vögeln [Frugivorie of central European birds]. PhD thesis, Faculty of mathematics and natural sciences, Carl-von-Ossietzki-University of Oldenburg, Wilhelmshaven, Germany, pp.
219. [in German]

Thompson K, Bakker J, Bekker R (1997). The soil seed banks of north west Europe: methodology, density and longevity. Cambridge University Press, Cambridge, UK, pp. 276.

Tiebel K, Huth F, Wagner S (2018). Soil seed banks of pioneer tree species in European temperate forests: a review. iForest 11: 48-57. - doi: 10.3832/ifor2400-011

Tiebel K, Huth Frischbier N, Wagner S (2020). Restrictions on natural regeneration of stormfelled spruce sites by silver birch (Betula pendula Roth) through limitations in fructification and seed dispersal. European Journal of Forest Research 139: 731-745. - doi: 10.1007/s10342-02001281-9

Toole EH, Brown E (1946). Final results of the Duvel buried seed experiment. Journal of Agricultural Research 72: 201-210.

Van TK, Rayamajhi MB, Center TD (2005). Seed longevity of Melaleuva quinquenervia: a burial experiment in South Florida. Journal of Aquatic Plant Management 43: 39-42.

Zhang Z, Gao P-L, Dai W-M, Song X-L, Hu F, Qiang $S$ (2019). Effect of tillage and burial depth and density of seed on viability and seedling emergence of weedy rice. Journal of Integrative Agriculture 18: 1914-192. - doi: 10.1016/S2095-311 $9(19) 62583$

Zobel M, Kalamees R, Püssa K, Roosaluste E, Moora M (2007). Soil seed bank and vegetation in mixed coniferous forest stands with different disturbance regimes. Forest Ecology and Management 250: 71-76. - doi: 10.1016/j.foreco.2007. 03.011

Zuur AF, leno EN, Walker NJ, Saveliev A, Smith $G M$ (2009). Mixed effects and extensions in ecology with R. Springer Science and Business Media, New York, USA, pp. 574. [online] URL: http://books.google.com/books?id=vQUNprFZK $\mathrm{HsC}$

Zywiec M, Holeksa J, Wesolowska M, Szewczyk J, Zwijacz-Kozica T, Kapusta P, Bruun HH (2013). Sorbus aucuparia regeneration in a coarsegrained spruce forest - a landscape scale. Journal of Vegetation Science 24: 735-743. - doi: 10.1111/j.1654-1103.2012.01493 